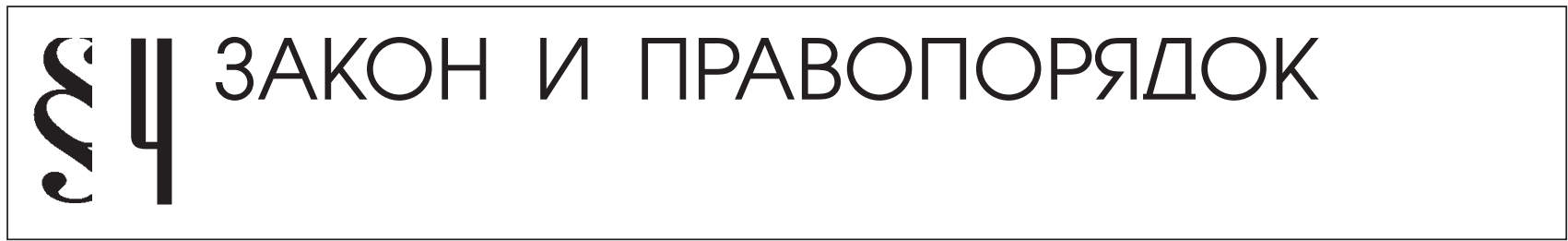

Панфилов А.Н.

\title{
ОХРАНИТЕЛЬНЫЕ НОРМЫ АДМИНИСТРАТИВНО-ДЕЛИКТНОГО ЗАКОНОДАТЕЛЬСТВА СУБЪЕКТОВ РОССИЙСКОЙ ФЕДЕРАЦИИ В СФЕРЕ ОХРАНЫ ОБЪЕКТОВ КУЛЬТУРНОГО НАСЛЕДИЯ
}

\begin{abstract}
Аннотация: В статье рассматриваются проблемы установления в законах субъектов Российской Федерации административной ответственности за правонарушения в области охраны объектов культурного наследия. На основе анализа обширного правового материала автор приходит к выводу о вторжении регионального законодателя в компетенцию федеральных органов государственной власти. Законами субъектов Федерачии об административных правонарушениях нередко устанавливается административная ответственность за нарушение правил и норм, предусмотренных федеральными нормативными правовыми актами. Охранительные нормы региональных законов зачастую противоречат федеральным нормам либо дублируют их. В связи с принятием и вступлением в силу в августе 2013 года Федерального закона от 7 мая 2013 г. № 96-Ф3 «О внесении изменений в Кодекс Российской Федерации об административных правонарушениях уже в ближайшее время в субъектах Российской Федераџии ожидаются кардинальные изменения в административно-деликтном законодательстве.

Ключевые слова: Юриспруденция, объекты культурного наследия, памятники истории и культуры, категории историко-культурного значения, административные правонарушения, административная ответственность, административный штраф, состав административного правонарушения, противоправные деяния, рассмотрение дел об административных правонарушен
\end{abstract}

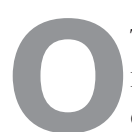

тношения в области охраны объектов культурного наследия в Российской Федерации регулируются Федеральным законом от 25 июня 2002 г. № 73-Ф3 «Об объектах культурного наследия (памятниках истории и культуры) народов Российской Федерации» (далее также - Федеральный закон № 73), а также принимаемыми в соответствии с ним другими федеральными законами, законами субъектов Российской Федерации и иными нормативными правовыми актами.

Согласно п. 1 ст. 33 Федерального закона № 73 объекты культурного наследия подлежат государственной охране в целях предотвращения их повреждения, разрушения или уничтожения, изменения облика и интерьера, нарушения установленного порядка их использования, перемещения и предотвращения других действий, могущих причинить вред объектам культурного наследия, а также в целях их защиты от неблагоприятного воздействия окружающей среды и от иных негативных воздействий. Государственная охрана памятников истории и культуры в Российской Федерации включает в себя установление от- ветственности за противоправные действия (бездействие) в отношении объектов культурного наследия, их территорий и зон охраны. Статьей 61 Федерального закона № 73 предусматривается уголовная, административная и иная юридическая ответственность должностных, физических и юридических лиц. Особое место в системе юридической ответственности занимает институт административной ответственности.

В соответствии с Конституцией России административное и административно-процессуальное законодательство находится в совместном ведении Российской Федерации и ее субъектов. Кодексом Российской Федерации об административных правонарушениях (далее - КоАП РФ) установлено, что законодательство об административных правонарушениях состоит из КоАП РФ и принимаемых в соответствии с ним законов субъектов Российской Федерации об административных правонарушениях. К ведению Российской Федерации относится установление административной ответственности по вопросам, имеющим федеральное значение, в том 
числе административной ответственности за нарушение правил и норм, предусмотренных федеральными законами и иными нормативными правовыми актами Российской Федерации. Субъекты РФ законами об административных правонарушениях устанавливают административную ответственность за нарушение законов и иных нормативных правовых актов субъектов РФ, нормативных правовых актов органов местного самоуправления.

В соответствии с задачами и принципами законодательства об административных правонарушениях в КоАП РФ установлена административная ответственность за нарушение норм, предусмотренных федеральными нормативными правовыми актами, регулирующими отношения в области охраны памятников. КоАП РФ содержит несколько составов административных правонарушений (ст.ст. 7.13 - 7.16, 7.33), объединенных общим объектом общественными отношениями, возникающими в связи с сохранением, использованием, популяризацией и охраной объектов культурного наследия. ${ }^{1}$

Согласно закрепленным в ст.ст. 7.13 - 7.16, 7.33 КоАП РФ составам административных правонарушений к противоправным деяниям, за совершение которых предусмотрена административная ответственность, относятся:

- $\quad$ нарушение требований сохранения, использования и охраны объектов культурного наследия федерального значения, их территорий, несоблюдение ограничений, установленных в зонах их охраны (ч. 1 ст. 7.13);

- действия (бездействие), предусмотренные ч. 1 ст. 7.13 , совершенные в отношении особо ценных объектов культурного наследия народов Российской Федерации, объектов культурного наследия, внесенных в Список всемирного культурного и природного наследия, на их территориях, на территориях историко-культурных заповедников (музеев-заповедников) федерального значения, а равно в зонах их охраны (ч. 2 ст. 7.13);

- действия (бездействие), предусмотренные ч. 1 ст. 7.13, совершенные в отношении выявленных объектов культурного наследия или на их территориях (ч. 3 ст. 7.13);

- проведение земляных, строительных, мелиоративных, хозяйственных и иных работ без разрешения государственного органа охраны объектов культурного наследия в случаях, если такое разрешение обязательно (ст. 7.14);

- $\quad$ ведение археологических разведок или раскопок без полученного в установленном порядке разрешения

\footnotetext{
${ }^{1}$ В настоящем исследовании мы не рассматриваем подробно новеллы Федерального закона от 7 мая 2013 г. № 96-Ф3 «О внесении изменений в Кодекс Российской Федерации об административных правонарушениях», который вступает в силу по истечении девяноста дней после его официального опубликования.
}

(открытого листа) либо с нарушением условий, предусмотренных разрешением (открытым листом) (ч. 1 ст. 7.15);

- действия, предусмотренные ч. 1 ст. 7.15, повлекшие по неосторожности повреждение или уничтожение объекта археологического наследия (ч. 2 ст. 7.15);

- $\quad$ незаконное предоставление земельных участков из состава земель историко-культурного назначения, незаконное изменение правового режима земельных участков из состава земель историко-культурного назначения (ст. 7.16);

- у уклонение от передачи обнаруженных в результате археологических полевых работ культурных ценностей (включая антропогенные, антропологические, палеозоологические, палеоботанические и иные объекты, имеющие историко-культурную ценность) на постоянное хранение в государственную часть Музейного фонда Российской Федерации (ст. 7.33).

Между тем действующая редакция КоАП РФ не предусматривает административную ответственность за нарушение требований сохранения, использования и охраны объектов культурного наследия регионального и местного (муниципального) значения, а также их территорий и зон охраны. Противоправные деяния в отношении памятников указанных категорий весьма проблематично, на наш взгляд, квалифицировать по ст. 7.14, поскольку существует неопределенность установления норм федерального законодательства, защищаемых ее административной санкцией. ${ }^{2}$

По замыслу федерального законодателя, установление административной ответственности за правонарушения, совершенные в отношении объектов культурного наследия регионального и местного (муниципального) значения, а также их территорий и зон охраны, должно было регулироваться законами субъектов РФ. Однако далеко не все регионы России реализовали это правотворческое полномочие. Так, 14 из 83 законов субъектов РФ об административных правонарушениях вообще не предусматривают административную ответственность за нарушения в сфере охраны памятников.

Анализ 69 административно-деликтных региональных законов, в которых установлена ответственность за указанные правонарушения, показывает, что в абсолютном большинстве своем они являются комплексными законами (97,1\%). Из них 73,9\% актов приняты в виде законов, в 16 регионах эти законодательные акты именуются кодексами $(23,2 \%)$. И лишь в двух субъектах РФ (Московская и Иркутская области) приняты тематические

\footnotetext{
2 Панфилов А.Н. Проблемы применения мер административной ответственности за отдельные правонарушения в сфере охраны объектов культурного наследия в Российской Федерации // Государство и право. 2012. № 8. С. 28 - 30.
} 


\section{Право и политика $6(162) \cdot 2013$}

законы, предусматривающие административную ответственность за правонарушения в сфере охраны объектов культурного наследия. ${ }^{3}$

В последнее время проблемы установления законами субъектов РФ об административных правонарушениях административной ответственности за нарушение законов и иных нормативных правовых актов субъектов РФ, нормативных правовых актов органов местного самоуправления находятся в центре внимания ученых-административистов. Многие из них справедливо критикуют региональное нормотворчество за его беспорядочность, отмечают такие недостатки законов субъектов РФ, как дублирование норм КоАП РФ, установление ответственности за нарушение правил, введенных на федеральном уровне. ${ }^{4}$ Внимание исследователей традиционно привлекают формулируемые региональным законодателем составы административных правонарушений, поскольку именно здесь наблюдается наибольшее вмешательство в федеральную юрисдикцию. Кроме того, в составах административных правонарушений должна проявляться региональная специфика. Однако, по наблюдениям М.Я. Масленникова, исследовавшего более семидесяти законов субъектов РФ, многие составы административных правонарушений не имеют никакой региональной специфики. ${ }^{5}$ Об отсутствии в законодательстве субъектов Федерации об административной ответственности региональных особенностей пишет О.С. Рогачева. ${ }^{6}$

Таким образом, требуют научного осмысления и разрешения проблемы установления составов административных правонарушений, а также размеров административных штрафов за правонарушения в сфере охраны

\footnotetext{
3 Закон Иркутской области от 08.06.2010 № 42-О3 (ред. от 17.10.2011) «Об административной ответственности за нарушения требований сохранения, использования и охраны объектов культурного наследия (памятников истории и культуры) народов Российской Федерации регионального и местного (муниципального) значения, их территорий и зон охраны в Иркутской области» // Областная. 2010. № 69. 21 июня.

${ }^{4}$ Салищева Н.Г. О некоторых тенденциях развития законодательства об административной ответственности в России в современный период // Административное право и процесс. 2009. № 5. C. 12. Рогачева О.С. К вопросу о необходимости модернизации законодательства Российской Федерации об административных правонарушениях // Административное право и процесс. 2011. № 11. С. 15-16. Гаврилова Л.В. Систематизация законодательства субъектов Российской Федерации об административной ответственности: опыт и проблемы // Академический юридический журнал. 2008. № 4 (34). С. 38.

${ }^{5}$ Масленников М.Я. О легитимности некоторых положений законов субъектов Российской Федерации об административной ответственности // Полицейское право. 2006. № 1. С. 57-58.

${ }^{6}$ Рогачева О.С. Эффективность норм административно-деликтного права: монография. Воронеж: Издательство Воронежского государственного университета. 2011. С. 5.
}

объектов культурного наследия в административно-деликтном законодательстве регионов.

В основном в анализируемых комплексных законах субъектов РФ административные правонарушения сгруппированы в главы по родовому объекту противоправного посягательства (88\%). Однако в восьми актах правонарушения не разграничиваются по родовому признаку, они содержатся в особенной части либо в общей главе «административные правонарушения». А Адинистративные правонарушения в сфере охраны памятников по аналогии с КоАП РФ чаще всего включаются в главы, где в качестве родового объекта выступают общественные отношения в области охраны собственности (31,3\%).

В 16 законах (23,9\%) административные правонарушения в сфере охраны объектов культурного наследия объединены в отдельные главы (Москва, Республика Бурятия, Республика Саха (Якутия), Кабардино-Балкарская Республика, Астраханская область, Волгоградская область и др.), в девяти актах (13,4\%) они, наряду с административными правонарушениями в других сферах общественной жизни, группируются в главы, в названии которых имеются указания на объекты культурного наследия.

В остальных случаях в качестве родового объекта выступают:

- права граждан, здоровый образ жизни, безопасность и отдых, общественный порядок (Республика Карелия);

- общественные отношения в области градостроительства, архитектуры, благоустройства и жилищно-коммунального хозяйства (Воронежская область);

- общественные отношения в области промышленности, градостроительства и энергетики (Нижегородская область);

- общественные отношения в области охраны собственности, окружающей среды и природопользования (Брянская область);

- $\quad$ установленный порядок управления (Тюменская область, Ямало-Ненецкий автономный округ) и др.

Представляется, что для удобства правоприменения административные правонарушения в области охраны объектов культурного наследия целесообразно включать в отдельную главу. При этом родовым объектом противоправного посягательства могли бы являться общественные отношения в сфере культуры.

В административно-деликтных законах субъектов РФ насчитывается 203 состава административных правонарушений в области охраны памятников. Составы включены в 121 статью. Преобладают законодательные акты, где содержится одна статья, включающая один

\footnotetext{
${ }^{7}$ Областной закон Новгородской области 01.07.2010 № 791-О3 (ред. от 03.10.2012) «Об административных правонарушениях», объединяющий составы административных правонарушений в 33 статьи, вообще не имеет глав.
} 
(16 актов), два (19 актов), три (10 актов) и более трех составов административных правонарушений (2 акта). В 22 законах составы закреплены в двух и более статьях. Лидерами по количеству статей и составов в них являются Кабардино-Балкарская Республика (6 статей/ 11 составов), Оренбургская область (5/9), Волгоградская область (7/7) и Московская область (5/8). Составы преимущественно формальные. Из 203 составов к материальным составам можно отнести лишь семь. Например, ч. 2 ст. 8.2 Кодекса Республики Дагестан об административных правонарушениях от 7 июня 2006 г. № 32 предусматривает ответственность за несообщение органам охраны памятников истории и культуры об обнаружении объекта, представляющего историческую или культурную ценность, повлекшее утрату такого объекта.

Все составы административных правонарушений можно условно разделить на две группы:

- составы, в которых противоправные деяния сформулированы обобщенно (неконкретно) по аналогии со статьей 7.13 КоАП РФ;

- составы, в которых противоправные деяния сформулированы конкретно.

В первом случае формулировки противоправных деяний начинаются со слов «нарушение требований сохранения, использования и охраны объектов культурного наследия», «нарушение правил сохранения, использования и охраны объектов культурного наследия» и др. Таких составов большинство - 112 (55,2\%).

Объективную сторону обобщенных (неконкретных) составов, как правило, образуют противоправные деяния, выраженные в нарушении требований сохранения, использования и охраны объектов культурного наследия регионального значения, местного (муниципального) значения, их территорий, а также несоблюдение ограничений, установленных в зонах их охраны. ${ }^{8}$ В ряде республик, краев и областей понятие «объект культурного наследия регионального значения» неправомерно подменяется понятиями: «объект культурного наследия республиканского значения», «объект культурного наследия краевого значения», «объект культурного наследия областного значения».

Данные составы административных правонарушений, включенные в большинство административно-деликтных законов субъектов Федерации, не что иное, как попытка регионального законодателя ликвидировать пробел в КоАП РФ - защитить административной санкцией общественные отношения в сфере сохранения, использования и охраны объектов культурного наследия регионального и местного

\footnotetext{
${ }^{8}$ См., например: ч. 1 ст. 4.4 Кодекса Республики Башкортостан об административных правонарушениях от 23.06.2011 № 413-3 (ред. от 19.07.2012) // Республика Башкортостан. 2011. № 127 (27362). 1 июля.
}

(муниципального) значения. Не случайно многие из них сформулированы так же, как и состав в ч. 1 ст. 7.13 КоАП РФ.

Однако законность их включения в региональные нормативные правовые акты весьма сомнительна. Дело в том, что требования сохранения, использования и охраны объектов культурного наследия федерального, регионального, местного (муниципального) значения и выявленных объектов культурного наследия установлены в федеральных законах и иных нормативных правовых актах Российской Федерации. Причем только в Федеральном законе № 73 можно насчитать более 70 таких правил и условий. Они касаются не только учета, государственной охраны, сохранения и содержания объектов культурного наследия, но и их территорий, зон охраны. В целом требования являются едиными для памятников истории и культуры, включенных в единый государственный реестр объектов культурного наследия (памятников истории и культуры) народов Российской Федерации (далее - peестр). Несколько отличаются требования в отношении выявленных объектов.

Вместе с тем законодательные акты субъектов РФ в области охраны недвижимого культурного наследия не устанавливают, да и не могут устанавливать особые требования охраны, сохранения и использования памятников, имеющих региональную и местную (муниципальную) категорию охраны, а также выявленных объектов. Фактически они осуществляют нормативное правовое регулирование лишь в той степени, в какой это дозволено федеральными нормами. Например, в соответствии с п. 2 ст. 27 Федерального закона № 73 порядок установки информационных надписей и обозначений на объекты культурного наследия регионального значения или объекты культурного наследия местного (муниципального) значения определяется законом субъекта Российской Федерации или муниципальным правовым актом. За нарушение порядка их установки административно-деликтным законом субъекта РФ могут быть предусмотрены административные наказания в виде предупреждения или административного штрафа. Однако региональный законодатель не вправе в нормативном правовом акте закрепить требование установки информационных надписей на выявленных объектах культурного наследия, поскольку это будет противоречить п. 1 ст. 27 указанного федерального закона.

В таком случае следует признать, что законы субъектов РФ об административных правонарушениях фактически предусматривают административную ответственность за нарушение правил и норм в сфере охраны объектов культурного наследия, установленных федеральными нормативными правовыми актами. В этой связи представляет интерес решение Сахалинского областного суда от 10 октября 2011 г. по делу № 3-30/2011, которым признаны противоречащи- 


\section{Право и политика $6(162) \cdot 2013$}

ми федеральному законодательству ряд статей Закона Сахалинской области «Об административных правонарушениях в Сахалинской области». ${ }^{9}$ В числе статей, признанных недействующими со дня вступления в законную силу решения суда, указана статья 22, предусматривающая административную ответственность за «нарушение требований по сохранению, использованию и охране объектов культурного наследия областного и местного значения...». С точки зрения Сахалинского областного суда, ей устанавливалась ответственность по вопросам, имеющим федеральное значение и урегулированным федеральным законодательством. Определением Верховного Суда РФ от 14 декабря 2011 г. № 64-Г11-36 данное решение оставлено без изменения.

Еще раньше к такому же выводу пришел Верховный Суд Республики Татарстан. ${ }^{10}$ В своем решении от 27 января 2006 г. он признал противоречащими федеральному законодательству статьи 6.1 - 6.4 Кодекса Республики Татарстан об административных правонарушениях, устанавливающие административную ответственность за нарушение требований по сохранению, использованию, охране объектов культурного наследия Республики Татарстан и местного значения. Однако определением Верховного Суда РФ от 26 апреля 2006 г. № 11-Г06-7 указанное решение Верховного Суда Республики Татарстан в части признания противоречащими федеральному законодательству статей 6.1 и 6.3 Кодекса Республики Татарстан об административных правонарушениях отменено.

В настоящее время очевидно, что административная ответственность за совершение противоправных деяний в отношении объектов культурного наследия регионального и местного (муниципального) значения, а также их территорий и зон охраны должна быть установлена КоАП РФ. Эту проблему должен был решить проект федерального закона № 163864-5. В статье 9 законопроекта формулировалась новая редакция статьи 7.13 КоАП РФ, предусматривающей в части первой административную ответственность за невыполнение установленных в соответствии с законодательством Российской Федерации требований к сохранению объекта культурного наследия независимо от его историко-культурного значения. На решение указанной проблемы был направлен и проект федерального закона «О внесении изменений в отдельные законодательные акты Российской Федерации в части пре-

\footnotetext{
${ }_{9}^{9}$ Решение Сахалинского областного суда от 10.10 .2011 по делу № 3-30/2011 «О признании частично недействующими отдельных положений Закона Сахалинской области от 29.03.2004 № 490 «Об административных правонарушениях в Сахалинской области»/ Губернские ведомости. 2012. 17 февраля. (№ 27).

${ }^{10}$ Решение Верховного суда Республики Татарстан от 27.01.2006 № 3П-1-5/06 «О признании недействующими отдельных положений Кодекса Республики Татарстан об административных правонарушениях»
}

сечения незаконной деятельности в области археологии» (законопроект № 217902-6), внесенный в Государственную Думу Федерального Собрания РФ на основании распоряжения Правительства РФ от 4 февраля 2013 г. № 106-р. Однако точку в этом вопросе поставил Федеральный закон от 7 мая 2013 г. № 96-Ф3 «О внесении изменений в Кодекс Российской Федерации об административных правонарушениях». ${ }^{11}$ В новой редакции противоправное деяние в ч. 1 ст. 7.13 КоАП РФ будет заключаться в «нарушении требований сохранения, использования и государственной охраны объектов культурного наследия (памятников истории и культуры) народов Российской Федерации, за исключением выявленных объектов культурного наследия, нарушении режима использования земель в границах территорий объектов культурного наследия, за исключением выявленных объектов культурного наследия, либо несоблюдении ограничений, установленных в границах зон охраны объектов культурного наследия, за исключением выявленных объектов культурного наследия».

В этой связи представительным органам государственной власти субъектов РФ потребуется провести ревизию соответствующих правовых норм законодательных актов об административных правонарушениях.

Отдельного рассмотрения заслуживают составы, в которых объективную сторону образуют противоправные деяния, выраженные в нарушении требований (правил) сохранения, использования и охраны выявленных объектов культурного наследия, а также их территорий. На начало 2013 года в 26 региональных законах об административных правонарушениях, содержались нормы об ответственности за противоправные деяния в отношении выявленных объектов культурного наследия, что составляет $37,7 \%$ от числа законов, предусматривающих административную ответственность за нарушения в сфере охраны памятников. Как минимум здесь следует говорить о дублировании федеральной охранительной нормы (ч. 3 ст. 7.13 КоАП РФ). Очевидно, что дублирование таких норм в региональных законах не только приводит к юридическим коллизиям, но и бесполезно, бесперспективно. Как верно пишет М.Ф. Казанцев, «Дублирование ведет к загромождению и запутыванию законодательства, увеличению в нем числа неясностей и противоречий. В результате снижается эффективность и авторитет регионального законодательства». ${ }^{12}$

\footnotetext{
${ }^{11}$ Внесен членом Совета Федерации Федерального Собрания РФ В.И. Матвиенко (законопроект № 168987-6). Принят Государственной Думой Федерального Собрания РФ в окончательной редакции 17 апреля 2013 г. (постановление от 17.04.2013 № 2075-6 ГД). Одобрен Советом Федерации 27 апреля 2013 г. (постановление от 27.04.2013 № 149-СФ).

${ }^{12}$ Казанцев М.Ф. Региональное законодательство: трудности роста // Вестник Уральского отделения РАН. 2009. № 2 (28). С. 31.
} 
Однако в ряде актов региональный законодатель не только продублировал состав административного правонарушения в ч. 3 ст. 7.13 КоАП РФ, но и дополнил диспозицию нормы противоречащими федеральному законодательству положениями. Например, в административно-деликтных законах Алтайского края, Воронежской, Костромской и Ленинградской областей установлена административная ответственность за несоблюдение ограничений в зонах охраны выявленных объектов культурного наследия. ${ }^{13}$ При этом Федеральный закон № 73 не предусматривает установление зон охраны в отношении такого рода объектов (п. 3 ст. 34). В нормативных правовых актах Кабардино-Балкарской Республики, Хабаровского края, Белгородской и Смоленской областей установлена административная ответственность за нарушение требований в отношении выявленных объектов культурного наследия регионального (республиканского, краевого) и местного (муниципального) значения. ${ }^{14}$ Вместе с тем классификация выявленных объектов культурного наследия по категории историко-культурного значения Федеральным законом № 73 не предусмотрена. Системный анализ положений федеральных нормативных правовых актов позволяет считать, что соответствующую категорию объект приобретает со дня вступления в силу нормативного правового акта уполномоченного органа государственной власти о включении его в реестр либо об изменении категории историко-культурного значения объекта культурного наследия. Основанием для принятия такого акта является заключение государственной историко-культурной экспертизы об обоснованности включения объекта культурного наследия в реестр, в котором лишь указывается рекомендуемая категория историко-культурного значения объекта культурного наследия, либо изменения категории историко-культурного значения объекта культурного наследия. ${ }^{15}$

Противоправные деяния, образующие объективную сторону конкретных составов административных правонарушений, в зависимости от объекта посягательства можно подразделить на несколько подгрупп.

${ }^{13}$ См.: Областной закон Ленинградской области от 02.07.2003 N 47-оз (ред. от 20.07.2012) «Об административных правонарушениях» // Вестник Правительства Ленинградской области. 2003. № 15. 23 июля. Закон Костромской области от 21.07.2008 № 352-4-3КО (ред. от 26.11.2012) «Кодекс Костромской области об административных правонарушениях» // СП - нормативные документы. 2008. № 33. 25 июля.

${ }^{14}$ См., например: ч. 3 ст. 41 Кодекса Хабаровского края об административных правонарушениях от 24.06.2009 № 256 (ред. от 23.11.2011) // Приамурские ведомости. 2009. № 104. 17 июля.

${ }^{15}$ См.: п. 20 Положения о государственной историко-культурной экспертизе, утвержденного постановлением Правительства Российской Федерации от 15.07.2009 № 569 (в ред. от 18.05.2011).
К первой подгруппе относятся противоправные деяния, выраженные в неисполнении обязанностей по установке на объектах культурного наследия регионального и местного (муниципального) значения информационных надписей и обозначений. Кроме того, к этой же подгруппе можно отнести:

- нарушение порядка согласования и установки информационных надписей и обозначений на объектах культурного наследия;

- $\quad$ нарушение срока установки информационных надписей и обозначений на объектах культурного наследия; - $\quad$ нарушение требований к содержанию в надлежащем виде установленных на объектах культурного наследия информационных надписей и обозначений;

- порчу, повреждение или снятие без соответствующего разрешения информационных надписей и обозначений на объекте культурного наследия.

Административная ответственность за указанные правонарушения установлена в законодательных актах 12 субъектов РФ (14 статей, 20 составов). В их числе: Москва, Кабардино-Балкарская Республика, Республика Башкортостан, Республика Саха (Якутия), Астраханская, Московская, Мурманская, Саратовская, Ульяновская области, Камчатский, Пермский и Приморский края. Субъектами правонарушений в основном являются собственники (юридические и физические лица) объектов культурного наследия регионального и местного (муниципального) значения. В ряде случаев (например, за содержание информационных надписей), ответственность возлагается и на пользователей таких объектов.

Ко второй подгруппе относятся противоправные деяния, проявляющиеся в уклонении от оформления (переоформления) охранного обязательства объекта культурного наследия регионального и местного (муниципального) значения. Данные правонарушения закреплены в административно-деликтных законах шести субъектов РФ (6 статей, 6 составов): Москва, КабардиноБалкарская Республика, Республика Башкортостан, Калининградская, Московская, Орловская области. Субъектами указанных правонарушений являются собственники и пользователи (юридические и физические лица) объектов культурного наследия регионального и местного (муниципального) значения.

Третью подгруппу составляют противоправные действия (бездействие), выраженные в воспрепятствовании доступу (отказе в доступе, ограничении доступа) граждан к объектам культурного наследия регионального и местного (муниципального) значения. Такие правонарушения нашли закрепление в законах пяти субъектов РФ (5 статей, 6 составов): Москва, Кабардино-Балкарская Республика, Республика Саха (Якутия), Московская и Мурманская области. Субъекты правонарушений - собственники и пользователи (юридические и физические лица) объектов 


\section{Право и политика $6(162) \cdot 2013$}

культурного наследия регионального и местного (муниципального) значения.

В четвертую подгруппу можно объединить деяния, выраженные в нарушении требований и несоблюдении ограничений, установленных в зонах охраны объектов культурного наследия регионального и местного (муниципального) значения. Административная ответственность за данные правонарушения установлена в законах пяти субъектов РФ (5 статей, 10 составов): Кабардино-Балкарская Республика, Республика Карелия, Архангельская, Московская и Нижегородская области. Причем в законодательных актах двух субъектов Федерации (Кабардино-Балкарская Республика, Московская область) соответствующие статьи включают в себя по три состава, где объективная сторона каждого состава формулируется в зависимости от вида зон охраны объекта культурного наследия. Например, ч. 1 ст. 4 Закона Московской области от 27.12.2008 № 220/2008-О3 предусматривает ответственность за нарушение требований и несоблюдение ограничений, установленных в границах охранной зоны объекта культурного наследия, ч. 2 - за нарушения в границах зоны регулирования застройки и хозяйственной деятельности объекта культурного наследия, ч. 3 - за нарушения в границах зоны охраняемого природного ландшафта объекта культурного наследия. ${ }^{16}$ Круг субъектов данных правонарушений весьма широк. К их числу могут относиться заказчики земляных, строительных, мелиоративных, хозяйственных и иных работ, подрядчики таких работ, собственники и пользователи объектов недвижимости, расположенных в зонах охраны памятников, и другие субъекты.

Иные противоправные деяния, составляющие объективную сторону конкретных составов административных правонарушений, можно рассматривать как оригинальные (неповторимые). К таковым деяниям, к примеру, относятся:

1. проведение работ по сохранению объекта культурного наследия регионального и местного (муниципального) значения без согласования заказчиком работ проектной документации на их проведение с органом исполнительной власти субъекта РФ, уполномоченным в области охраны объектов культурного наследия, либо с отступлением от согласованной проектной документации;

2. привлечение заказчиком к проведению работ по сохранению объекта культурного наследия региональ-

\footnotetext{
16 Закон Московской области от 27.12.2008 № 220/2008-О3 (ред. от 22.01 .2013 ) «Об административной ответственности за правонарушения в области сохранения, использования и государственной охраны объектов культурного наследия (памятников истории и культуры) народов Российской Федерации регионального (областного) значения и местного (муниципального) значения, расположенных на территории Московской области» // Ежедневные Новости. Подмосковье. 2008. № 285. 30 декабря.
}

ного и местного (муниципального) значения лиц, не имеющих лицензии на осуществление деятельности по реставрации объектов культурного наследия:17

3. нарушение сроков рассмотрения представления исполнительного органа государственной власти, уполномоченного в области охраны объектов культурного наследия, об ограничении или запрещении движения транспортных средств на территории объекта культурного наследия или в его зонах охраны в связи с угрозой нарушения целостности и сохранности объекта культурного наследия; ${ }^{18}$

4. использование объекта культурного наследия регионального и местного (муниципального) значения с нарушением требований к его содержанию и сохранению, повлекшее ухудшение состояния объекта культурного наследия. ${ }^{19}$

Исследование составов административных правонарушений, в которых противоправные деяния сформулированы конкретно, свидетельствует о вторжении регионального законодателя в компетенцию федеральных органов государственной власти. Административно-деликтными законами субъектов РФ нередко устанавливается административная ответственность за нарушение правил и норм, предусмотренных федеральными законами и иными нормативными правовыми актами Российской Федерации.

Представляется проблематичным включение в региональные законы норм, устанавливающих административную ответственность за противоправные деяния, выраженные:

- в воспрепятствовании доступу (отказе в доступе, ограничении доступа) граждан к объектам культурного наследия регионального и местного значения;

- в нарушении требований и несоблюдении ограничений, установленных в зонах охраны объектов культурного наследия регионального и местного значения;

- $\quad$ в проведении работ по сохранению объекта культурного наследия регионального и местного значения без согласованной проектной документации, либо с отступлением от согласованной проектной документации;

\footnotetext{
${ }^{17}$ См.: ч. 1 и ч. 2 ст. 6.7.1 Кодекса Нижегородской области об административных правонарушениях от 20.05.2003 № 34-3 (ред. от 07.12.2012) // Правовая среда. 2003. № 18-19 (464-465). 28 мая (приложение к газете Нижегородские новости. 2003. № 93(2785). 28 мая).

${ }^{18}$ См.: ст. 26 Закона Астраханской области от 04.09.2007 № 49/2007О3 (ред. от 07.11.2012) «Об административных правонарушениях» // Сборник законов и нормативных правовых актов Астраханской области. 2007. № 40. 10 сентября.

${ }^{19}$ См.: ст. 65 Закона Республики Бурятия от 05.05.2011 № 2003-IV (ред. от 09.07.2012) «Об административных правонарушениях» // Бурятия. 2011. № 79. 7 мая.
} 
- $\quad$ в привлечении к проведению работ по сохранению объекта культурного наследия регионального и местного значения лиц, не имеющих соответствующей лицензии.

Такой вывод напрашивается при системном анализе норм федеральных и региональных нормативных правовых актов, регулирующих отношения в области охраны объектов культурного наследия. Рассмотрим высказанный тезис на следующем примере.

Федеральный закон № 73-Ф3 «Об объектах культурного наследия (памятниках истории и культуры) народов Российской Федерации» в соответствии с Конституцией России в п. 2 ст. 7 закрепляет право каждого на доступ к объектам культурного наследия. При этом доступ к памятникам независимо от категории историко-культурного значения должен обеспечиваться в порядке, установленном п. 3 ст. 52 данного законодательного акта. Согласно определенным в п. 3 ст. 52 требованиям к использованию объекта культурного наследия, включенного в реестр, условия доступа к нему устанавливаются собственником объекта культурного наследия по согласованию с соответствующим органом охраны объектов культурного наследия. Федеральный закон № 73 также содержит иные правовые нормы, гарантирующие предоставление гражданам доступа к памятникам истории и культуры:

- при государственной регистрации права собственности на объект культурного наследия собственник принимает на себя являющиеся ограничениями (обременениями) права собственности на данный объект и указываемые в охранном обязательстве собственника объекта культурного наследия требования к условиям доступа к нему граждан (п. 4 ст. 48);

- при отчуждении объекта культурного наследия из государственной или муниципальной собственности новый собственник принимает на себя обязательства по выполнению требований к условиям доступа к нему граждан, которые являются ограничениями (обременениями) права собственности на данный объект и указываются в охранном обязательстве собственника объекта культурного наследия (п. 4 ст. 50);

- охранное обязательство пользователя объектом культурного наследия должно включать в себя требования к условиям доступа к нему граждан, а также иные требования, которые обеспечивают сохранность данного объекта и являются ограничениями (обременениями) права пользования данным объектом (п. 5 ст. 55).

Между тем в законодательных актах об охране памятников, принятых в тех субъектах РФ, где предусмотрена административная ответственность за отказ в доступе граждан к объектам культурного наследия, данные общественные отношения в основном не урегулированы. Например, в п. 2 ст. 7 Закона КабардиноБалкарской Республики «Об объектах культурного наследия (памятниках истории и культуры) народов Кабардино-Балкарской Республики» лишь дублируется конституционное положение о праве каждого на доступ к памятникам истории и культуры, а п. 2 ст. 9 содержит отсылочную норму о том, что особенности пользования объектом культурного наследия определяются законодательством Российской Федерации. ${ }^{20}$ Напротив, в Законе г. Москвы «Об охране и использовании недвижимых памятников истории и культуры» указанные отношения регулируются статьей, устанавливающей, что порядок и условия общественной доступности каждого конкретного недвижимого памятника истории и культуры определяются наличием в составе охранной документации на недвижимый памятник специального раздела, включающего в себя график посещений памятника гражданами и план его осмотра. ${ }^{21}$ Согласно ст. 19 график посещений памятника устанавливается собственником или пользователем памятника в соответствии с режимом и характером его использования по согласованию с государственным органом охраны объектов культурного наследия. Также обязанность пользователей и собственников памятников по обеспечению их общественной доступности предусмотрена в ч. 2 ст. 22 Закона г. Москвы. Необходимость включения требований к условиям доступа граждан к объекту культурного наследия в охранное обязательство собственника объекта культурного наследия закреплена в Законе Республики Саха (Якутия) от 6 февраля 1997 г. 3 № 155-I «О государственной охране памятников истории и культуры Республики Саха (Якутия)» и в законодательных актах некоторых других субъектов РФ.

Таким образом, требования к обеспечению доступа граждан к объектам культурного наследия установлены Федеральным законом № 73, в то время как законы субъектов РФ только лишь дублируют эти требования. В единичных случаях можно говорить о конкретизации его положений. Соответственно административная ответственность за данное противоправное деяние должна быть установлена КоАП РФ.

В отдельную подгруппу конкретных составов административных правонарушений мы выделяем составы, в которых объективную сторону составляют противоправные деяния, не основанные на нормах права или противоречащие им. Такие составы можно назвать сомнительными или надуманными. Нередко

\footnotetext{
20 Закон Кабардино-Балкарской Республики от 10.04.2003 № 39-Р3 (ред. от 13.11.2012) «Об объектах культурного наследия (памятниках истории и культуры) народов Кабардино-Балкарской Республики» // Кабардино-Балкарская правда. 2003. № 96-97. 15 апреля.

${ }^{21}$ См.: ст. 19 Закона г. Москвы от 14.07.2000 № 26 (ред. от 06.07.2011) «Об охране и использовании недвижимых памятников истории и культуры» // Вестник Мэрии Москвы. 2000. № 27. Октябрь.
} 


\section{Право и политика $6(162) \cdot 2013$}

они создают юридические коллизии и сложности в правоприменительной практике.

К сомнительным составам административных правонарушений можно отнести состав правонарушения, предусмотренного ст. 34 Закона Алтайского края «Об административной ответственности за совершение правонарушений на территории Алтайского края». Его объективная сторона включает в себя нарушение правил сохранения, использования и охраны объектов, обладающих признаками объекта культурного наследия, а также их территорий и зон охраны. ${ }^{22}$ Однако ни Федеральный закон № 73, ни Закон Алтайского края «Об объектах культурного наследия (памятниках истории и культуры) в Алтайском крае» не устанавливают правила сохранения, использования и охраны объектов с признаками объекта культурного наследия. ${ }^{23}$ Тем более законодательство не содержит в отношении указанных объектов каких-либо требований по установлению границ территорий и зон охраны.

Иногда сомнительные составы приводят к оспариванию квалификации административного правонарушения в суде. Ярким примером может служить постановление Калининградского областного суда от 13 июня 2012 г. по делу № 4-Аг-219/2012. Данным актом изменено постановление мирового судьи 1 судебного участка Зеленоградского района Калининградской области и решение судьи Зеленоградского районного суда Калининградской области от 27 марта 2012 г.: переквалифицированы действия ООО «Научнопроизводственная фирма «ГАМАС» со ст. 32 Кодекса Калининградской области об административных правонарушениях на ч. 2 ст. 7.15 КоАП РФ и снижен размер назначенного административного штрафа до 50000 руб. Указанной статьей Кодекса Калининградской области об административных правонарушениях установлена ответственность в виде административного штрафа за нарушение порядка производства археологических, проектных, строительных, научно-исследовательских, ремонтных, реставрационных и иных работ на объектах культурного наследия регионального и местного значения, а также выявленных объектах культурного наследия. ${ }^{24}$ При этом размер налагаемого на юридических

\footnotetext{
22 Закон Алтайского края от 10.07.2002 N 46-3С (ред. от 05.12.2012) «Об административной ответственности за совершение правонарушений на территории Алтайского края» // Алтайская правда. 2002. № 193-196. 26 июля.

23 Закон Алтайского края от 12.05.2005 № 32-3С (ред. от 09.10.2012) «Об объектах культурного наследия (памятниках истории и культуры) в Алтайском крае» // Алтайская правда. 2005. № 140-141. 19 мая.

24 Закон Калининградской области от 12.05.2008 № 244 (ред. от 18.03.2013) «Кодекс Калининградской области об административных правонарушениях» // Калининградская правда. 2008. № 89. 21 мая.
}

лиц административного штрафа - от пятисот тысяч до одного миллиона рублей.

Подобных примеров конструирования надуманных составов правонарушений в административно-деликтных законах субъектов РФ можно назвать немало. Известны случаи, когда региональными законами устанавливается административная ответственность граждан, должностных и юридических лиц за уничтожение (снос, перемещение) памятника истории и культуры (например, ч. 3 ст. 13 Закона Оренбургской области «Об административных правонарушениях в Оренбургской области). ${ }^{25}$ Тем самым, законодателем минимизируется ответственность физических лиц за противоправное деяние, за которое ст. 243 Уголовного кодекса Российской Федерации предусмотрена уголовная ответственность.

К сомнительным составам административных правонарушений можно отнести составы в ч. 1 и в ч. 2 ст. 8.2 Кодекса Республики Дагестан об административных правонарушениях. ${ }^{26}$ Часть первая указанной статьи предусматривает ответственность за несообщение органам охраны памятников истории и культуры об обнаружении объекта, представляющего историческую или культурную ценность. Вторая - ответственность за те же действия (бездействие), повлекшие утрату такого объекта (материальный состав).

Во-первых, весьма проблематично, на наш взгляд, квалифицировать деяние по данной статье, поскольку лицо, осуществляющее какую-либо деятельность (земляные, хозяйственные и прочие работы), в том числе культурную и туристскую деятельность, должно отчетливо понимать, что обнаруженный им (лицом) объект представляет историческую или культурную ценность. Для этого лицо должно обладать некоторыми познаниями в области археологии, архитектуры, искусства. Например, камень, поднятый со дна водоема или с поверхности земли, может оказаться древним орудием, но определить это под силу только специалисту.

Во-вторых, обязанность исполнителя работ проинформировать орган исполнительной власти субъекта РФ, уполномоченный в области охраны объектов культурного наследия, об обнаруженном объекте, обладающем признаками объекта культурного наследия, установлена

\footnotetext{
25 Закон Оренбургской области от 01.10.2003 № 489/55-III-О3 (ред. от 06.11.2012) «Об административных правонарушениях в Оренбургской области» // Южный Урал. 2003. № 210. 28 октября. Кодекс Томской области об административных правонарушениях от 26.12.2008 № 295-О3 (ред. от 16.10.2012) // Томский вестник. 2009. № 10. 24 января.

${ }^{26}$ Кодекс Республики Дагестан об административных правонарушениях от 07.06.2006 № 32 (ред. от 05.10.2012) // Дагестанская правда. 2006. № 147-148. 14 июня.
} 
ст. 37 Федерального закона № 73. Закон Республики Дагестан «Об объектах культурного наследия (памятниках истории и культуры) народов Российской Федерации, расположенных на территории Республики Дагестан» не содержит такого требования. ${ }^{27}$

В-третьих, думается, что ч. 2 ст. 8.2 Кодекса Республики Дагестан об административных правонарушениях, не содержащая указания на форму вины, фактически минимизирует ответственность субъектов за уничтожение объекта, представляющего историко-культурную ценность (см. п. 1 ст. 18 Федерального закона № 73). Максимальный размер административного штрафа за данное правонарушение, возложенный на граждан, составляет две тысячи рублей, на должностных лиц - три с половиной тысячи рублей, на юридических лиц - 20 тысяч рублей. Однако правонарушитель может отделаться и предупреждением.

Кроме того, несообщение об обнаруженном объекте является бездействием, если обязанность сообщить о нем установлена нормативным правовым актом, а не действием как закреплено в Кодексе Республики Дагестан.

Противоречит положениям Федерального закона № 73 п. 2 ст. 7 Закона Свердловской области «Об административных правонарушениях на территории Свердловской области», которым предусматривается ответственность за нарушение установленных нормативными правовыми актами Свердловской области требований при проектировании и проведении землеустроительных, земляных, строительных, мелиоративных, хозяйственных и иных работ на территории объекта культурного наследия областного и местного (муниципального) значения. ${ }^{28}$ Вместе с тем п. 2 ст. 35 Федерального закона № 73 устанавливает режим использования территории памятника или ансамбля, запрещающий проектирование и проведение землеустроительных, земляных, строительных, мелиоративных, хозяйственных и иных работ, за исключением работ по сохранению данных объектов культурного наследия и (или) их территорий, а также хозяйственной деятельности, не нарушающей их целостности и не создающей угрозы их повреждения, разрушения или уничтожения.

Таким образом, анализ административно-деликтных законов субъектов РФ дает основание говорить о существенных недостатках в формулировках противоправных деяний в составах административных правонарушений в сфере охраны объектов культурного наследия.

\footnotetext{
${ }^{27}$ Закон Республики Дагестан от 03.02.2009 № 7 (ред. от 02.11.2012) «Об объектах культурного наследия (памятниках истории и культуры) народов Российской Федерации, расположенных на территории Республики Дагестан» // Дагестанская правда. 2009. №o 30-32. 5 февраля.

28 Закон Свердловской области от 14.06.2005 № 52-О3 (ред. от 25.04.2012) «Об административных правонарушениях на территории Свердловской области» // Областная газета. 2005. № 170-171. 15 июня.
}

В исследовании А.К. Вахитова, посвященном административно-правовой охране объектов культурного наследия, сделан вывод о вторжении регионального законодателя в предметы ведения Российской Федерации путем установления административной ответственности за деяния, предусмотренные КоАП РФ, а также за нарушение правил и норм, предусмотренных федеральными законами и другими нормативными правовыми актами Российской Федерации. ${ }^{29}$ В связи с этим указанный автор предложил полностью урегулировать административную ответственность за нарушение законодательства об охране объектов культурного наследия КоАП РФ, исключив региональное правотворчество в данной области.

Однако с таким предложением можно согласиться лишь отчасти. Как отмечает М.Я. Масленников, законы об административной ответственности субъектов РФ призваны обеспечить неотвратимость административной ответственности граждан, должностных лиц и юридических лиц за нарушения законов и иных нормативных правовых актов в случаях, не установленных федеральным законодательством. ${ }^{30}$

Очевидно, что если в соответствии со ст. 38 Федерального закона № 73 законом субъекта РФ установлен порядок ограничения движения транспортных средств на территории объекта культурного наследия и в зонах охраны объекта культурного наследия, то и административная ответственность за нарушение такого порядка должна быть установлена соответствующим региональным законом. Также это касается порядка установки информационных надписей и обозначений на объекты культурного наследия регионального значения или объекты культурного наследия местного (муниципального) значения и ряда других вопросов. В противном случае Федеральный закон № 73 не должен содержать отсылочных норм, возлагающих на субъекты РФ обязанность нормативного правового регулирования тех или иных общественных отношений.

За совершение административных правонарушений в сфере охраны объектов культурного наследия, предусмотренных в административно-деликтных законах субъектов РФ, преимущественно установлено наказание в виде административного штрафа. Тем не менее в законодательных актах 13 субъектов РФ мерой административного наказания наряду с административным штрафом является предупреждение.

\footnotetext{
29 Вахитов А.К. Административно-правовая охрана объектов культурного наследия: автореф. дис. ... канд.юрид.наук: 12.00.14. M., 2007. C. 24.

${ }^{30}$ Масленников М.Я. Обстоятельная концепция необходима каждому региональному закону об административной ответственности // Административное право и процесс. 2007. № 6. С. 2 - 7.
} 


\section{Право и политика $6(162) \cdot 2013$}

Весьма важен вопрос о размерах административных штрафов. Согласно действующей редакции КоАП РФ граждане могут быть подвергнуты денежному взысканию в размере от пятисот до двух тысяч пятисот рублей, должностные лица - от одной тысячи до пяти тысяч рублей, юридические лица - от десяти тысяч до ста тысяч рублей. При этом наибольший размер штрафа (от пятидесяти до ста тысяч рублей) может применяться в отношении юридических лиц, действия которых повлекли по неосторожности повреждение или уничтожение объекта археологического наследия (ч. 2 ст. 7.15). Следует заметить, что по общему правилу, установленному в ч. 1 ст. 3.5 КоАП РФ, максимальный размер административного штрафа для граждан - пять тысяч рублей, для должностных лиц - пятьдесят тысяч рублей, для юридических лиц - один миллион рублей. Кроме того, в случаях, предусмотренных рядом статей КоАП РФ, размеры административных штрафов могут достигать для граждан - трехсот тысяч рублей, для должностных лиц - шестисот тысяч рублей, для юридических лиц - пяти миллионов рублей.

С вступлением в силу Федерального закона от 7 мая 2013 г. № 96-Ф3 «О внесении изменений в Кодекс Российской Федерации об административных правонарушениях» (далее - Федеральный закон № 96-Ф3) размеры административных штрафов за нарушение требований в сфере охраны памятников значительно возрастут. Например, санкция в ч. 1 ст. 7.13 КоАП РФ в новой редакции предусматривает следующие размеры административных штрафов: для граждан - от пятнадцати тысяч до двухсот тысяч рублей, для должностных лиц - от двадцати тысяч до четырехсот тысяч рублей, для юридических лиц от двухсот тысяч до пяти миллионов рублей. Уничтожение или повреждение объекта культурного наследия любой категории историко-культурного значения, а также выявленного объекта культурного наследия повлечет наложение административного штрафа на юридических лиц в размере от пятисот тысяч до двадцати миллионов рублей (ч. 1 ст. 7.14.1 КоАП РФ).

В отличие от КоАП РФ в действующей редакции административно-деликтные законы ряда субъектов РФ за административные правонарушения в данной сфере предусматривают наказание в виде административного штрафа в отношении юридических лиц в размере: от 500 тыс. руб. до 1000 тыс. руб. (Москва, Республика Саха (Якутия), Республика Татарстан (Татарстан), Калининградская область). В последние годы просматривается явная тенденция к увеличению размеров административных штрафов в других регионах России. К примеру, Законом Московской области от 22 января 2013 г. № 4/2013-О3 значительно повышены размеры штрафов за правонарушения, предусмотренные Законом Московской области «Об административной ответственности за правонарушения в области сохранения, использования и государственной охраны объектов культурного наследия (памятников истории и культуры) народов Российской Федерации регионального (областного) значения и местного (муниципального) значения, расположенных на территории Московской области». ${ }^{31}$ Прежде всего, увеличение размеров штрафов коснулось должностных и юридических лиц. Так, если до вступления в силу Закона Московской области от 22 января 2013 г. № 4/2013-О3 максимальный размер административного штрафа в отношении юридического лица составлял 50000 рублей, то после вступления в силу этого акта он увеличился в 10 раз. Однако в большинстве субъектов РФ размеры штрафных санкций за правонарушения в области сохранения, использования и охраны объектов культурного наследия по-прежнему соответствуют размерам штрафов, установленных в действующей редакции КоАП РФ.

До вступления в силу Федерального закона № 96-Ф3 к кругу субъектов применения административной ответственности за правонарушения, предусмотренные ст.ст. 7.13 - 7.16, 7.33 КоАП РФ, относятся органы, осуществляющие государственный контроль в области сохранения, использования, популяризации объектов культурного наследия и их государственную охрану, и мировые судьи. Последние уполномочены рассматривать дела об административных правонарушениях, предусмотренных статьей 7.15. Протоколы об административных правонарушениях составляются должностными лицами органов, осуществляющих государственный контроль в области сохранения, использования, популяризации и государственной охраны объектов культурного наследия (ст.ст. $7.13,7.14,7.15,7.16,7.33)$, должностными лицами органов внутренних дел (полиции) (ст.ст. 7.13, 7.14, 7.15).

Новеллы Федерального закона № 96-ФЗ особую роль в рассмотрении дел об административных правонарушениях в сфере охраны памятников отводят судьям районных судов. Им будут подведомственны дела об административных правонарушениях, предусмотренных статьями 7.13 7.16 КоАП РФ. Напротив, административная юрисдикция органов, осуществляющих государственный контроль в области государственной охраны памятников, сузится. В их компетенции останется лишь рассмотрение дел об административных правонарушениях, предусмотренных ст. 7.33 КоАП РФ.

Круг субъектов применения административной ответственности за правонарушения в области сохранения,

\footnotetext{
31 Закон Московской области от 22.01.2013 № 4/2013-О3 «О внесении изменений в Закон Московской области «Об административной ответственности за правонарушения в области сохранения, использования и государственной охраны объектов культурного наследия (памятников истории и культуры) народов Российской Федерации регионального (областного) значения и местного (муниципального) значения, расположенных на территории Московской области» // Ежедневные Новости. Подмосковье. 2013. № 16.31 января.
} 
использования и охраны объектов культурного наследия, предусмотренные региональными административно-деликтными законами, более широкий. К ним относятся:

- органы исполнительной власти субъектов РФ, уполномоченные в области охраны объектов культурного наследия (органы исполнительной власти субъектов РФ, уполномоченные осуществлять государственный контроль в области сохранения, использования, популяризации и государственной охраны объектов культурного наследия) - в 39 законах;

- учреждения органов исполнительной власти субъектов РФ, уполномоченных в области охраны объектов культурного наследия - в законе Краснодарского края;

- $\quad$ иные органы исполнительной власти субъектов РФ либо органы в законе не определены - в 4 законах (Республики Алтай и Карелия, Воронежская и Тамбовская области); ${ }^{32}$

- $\quad$ мировые судьи - в 14 законах;

- административные комиссии (субъектов РФ и муниципальных образований) - в 20 законах.

Чаще всего дела об административных правонарушениях в области охраны объектов культурного наследия, предусмотренных законами субъектов РФ, рассматриваются одним органом административной юрисдикции (в 53 актах). Однако нередко в одном субъекте РФ такие дела подведомственны двум и более субъектам административной юрисдикции (в 9 актах). В основном это административные комиссии муниципальных образований и органы исполнительной власти субъектов РФ, уполномоченные в области охраны объектов культурного наследия. ${ }^{33}$ Причем разграничение полномочий между ними осуществляется, как правило, в зависимости от категории историко-культурного значения объекта культурного наследия. ${ }^{34}$ Дела об административных правонарушениях,

\footnotetext{
${ }^{32}$ В Республике Алтай - государственные учреждения, подведомственные исполнительному органу государственной власти Республики Алтай, уполномоченному в соответствии с федеральными законами на осуществление государственного надзора в области использования и охраны особо охраняемых природных территорий на особо охраняемых природных территориях республиканского значения; В Законе Воронежской области от 31.12.2003 № 74-О3 «Об административных правонарушениях на территории Воронежской области» - исполнительный орган государственной власти Воронежской области, уполномоченный на осуществление государственного строительного надзора.

33 Закон Республики Хакасия от 17.12.2008 № 91-3РХ (ред. от 20.12.2012) «Об административных правонарушениях // Вестник Хакасии. 2008. № 79. 23 декабря. Закон Чувашской Республики от 23.07.2003 № 22 (ред. от 30.07.2012) «Об административных правонарушениях в Чувашской Республике» // Республика. 2003. № 30.30 июля.

34 Закон Вологодской области от 08.12.2010 № 2429-ОЗ (ред. от 05.12.2012) «Об административных правонарушениях в Вологодской области» // Красный Север. 2010. № 139. 11 декабря.
}

совершенных в отношении памятников регионального значения, рассматривают органы исполнительной власти субъектов РФ, в отношении памятников местного значения - административные комиссии муниципальных образований. Вместе с тем в ряде законодательных актов административные комиссии муниципальных образований, являющиеся единственным субъектом применения административной ответственности, рассматривают дела независимо от категории историко-культурного значения объекта (Республика Саха (Якутия), Приморский, Хабаровский края, Иркутская, Костромская, Орловская, Самарская, Свердловская, Томская области). ${ }^{35}$

Протоколы об административных правонарушениях в данной сфере уполномочены составлять:

- д должностные лица органов исполнительной власти субъектов РФ, уполномоченных в области охраны объектов культурного наследия - в 57 законах;

- должностные лица учреждений органов исполнительной власти субъектов РФ, уполномоченных в области охраны объектов культурного наследия - в 1 законе;

- должностные лица иных органов исполнительной власти субъектов РФ либо должностные лица органов, не установленных законом - в 11 законах;

- должностные лица органов внутренних дел (полиции) - в восьми законах;

- д должностные лица органов местного самоуправления - в 22 законах;

- $\quad$ члены административных комиссий - в двух законах. В административно-деликтных законах, устанавливающих порядок, при котором протоколы об административных правонарушениях в сфере охраны памятников уполномочены составлять должностные лица органов исполнительной власти субъектов РФ и должностные лица органов местного самоуправления, разграничение полномочий по их составлению осуществляется в основном по тому же принципу, что и рассмотрение дел - в зависимости от категории историко-культурного значения объекта (Волгоградская, Липецкая, Ростовская области и др.). Например, в соответствии с «Кодексом Волгоградской области об административной ответственности» протоколы об административных правонарушениях, предусмотренных ст.ст. 10.1 - 10.3, составляются должностными лицами органа исполнительной власти Волгоградской области, осуществляющего реализацию государственной политики в сфере охраны и использования историко-культурного наследия, а об административных правонарушениях, предусмотренных ст.ст. 10.4 - 10.7 - должностными лицами

\footnotetext{
${ }^{35}$ См., например: Закон Орловской области от 04.02.2003 № 304-О3 (ред. от 03.10.2012) «Об ответственности за административные правонарушения» // Орловская правда. 2003. № 24.7 февраля.
} 


\section{Право и политика $6(162) \cdot 2013$}

органов местного самоуправления, уполномоченных в сфере охраны и использования объектов культурного наследия местного (муниципального) значения. ${ }^{36}$

В некоторых случаях должностные лица органов местного самоуправления, наделенных законом субъекта РФ соответствующими полномочиями, вправе составлять протоколы за правонарушения, совершенные как в отношении объектов культурного наследия местного (муниципального) значения, так и в отношении объектов региональной категории охраны. ${ }^{37}$

Следует отметить, что в науке административного права административно-юрисдикционная деятельность органов публичной власти в области охраны памятников недостаточно изучена. Однако указанная проблема является предметом самостоятельного исследования.

В последние несколько лет в субъектах РФ наблюдается незначительная активизация работы по совершенствованию охранительных юридических норм, обеспечивающих защиту объектов культурного наследия от противоправных деяний. Этот неспешный процесс идет по пути уточнения и детализации составов административных правонарушений, а также усиления административной ответственности. В связи с принятием и вступлением в силу в августе 2013 года Федерального закона № 96-Ф3 уже в ближайшее время в субъектах РФ ожидаются кардинальные изменения в административно-деликтном законодательстве. Прежде всего, от регионального законодателя во избежание дублирования федеральных охранительных норм потребуется признать утратившими силу составы, предусматривающие ответственность за нарушение требований сохранения, использования и охраны объектов культурного наследия регионального и местного (муниципального) значения, а также их территорий и зон охраны. По-видимому, это будет сопровождаться включением в административноделиктные законы конкретных составов административных правонарушений, которые должны соответствовать регулятивным нормам, закрепленным в региональных нормативных правовых актах.

\section{Библиография:}

1. Вахитов А.К. Административно-правовая охрана объектов культурного наследия: автореф. дис. ... канд.юрид.наук: 12.00.14. М., 2007.

\footnotetext{
36 Закон Волгоградской области от 11.06.2008 № 1693-ОД (ред. от 12.11.2012) «Кодекс Волгоградской области об административной ответственности» // Волгоградская правда. 2008. № 105. 18 июня.

37 Закон Еврейской автономной области от 23.06.2010 № 781-О3 (ред. от 24.12.2012) «Об административных правонарушениях» // Биробиджанер штерн. 2010. № 48. 2 июля.
}

2. Гаврилова Л.В. Систематизация законодательства субъектов Российской Федерации об административной ответственности: опыт и проблемы // Академический юридический журнал. 2008. № 4 (34).

3. Казанцев М.Ф. Региональное законодательство: трудности роста // Вестник Уральского отделения РАН. 2009. № 2 (28).

4. Масленников М.Я. О легитимности некоторых положений законов субъектов Российской Федерации об административной ответственности // Полицейское право. 2006. № 1.

5. Масленников М.Я. Обстоятельная концепция необходима каждому региональному закону об административной ответственности // Административное право и процесс. 2007. № 6.

6. Рогачева О.С. К вопросу о необходимости модернизации законодательства Российской Федерации об административных правонарушениях // Административное право и процесс. 2011. № 11.

7. Рогачева О.С. Эффективность норм административно-деликтного права: монография. Воронеж: Издательство Воронежского государственного университета. 2011.

8. Салищева Н.Г. О некоторых тенденциях развития законодательства об административной ответственности в России в современный период // Административное право и процесс. 2009. № 5.

\section{References (transliteration):}

- Vahitov A.K. Administrativno-pravovaya ohrana ob'ektov kul'turnogo naslediya: avtoref. dis. ... kand. yurid.nauk: 12.00.14. M., 2007.

- Gavrilova L.V. Sistematizaciya zakonodatel'stva sub'ektov Rossiyskoy Federacii ob administrativnoy otvetstvennosti: opyt i problemy // Akademicheskiy yuridicheskiy zhurnal. 2008. № 4 (34).

- Kazancev M.F. Regional'noe zakonodatel'stvo: trudnosti rosta // Vestnik Ural'skogo otdeleniya RAN. 2009. № 2 (28).

- Maslennikov M.Ya. O legitimnosti nekotoryh polozheniy zakonov sub'ektov Rossiyskoy Federacii ob administrativnoy otvetstvennosti // Policeyskoe pravo. 2006. № 1 .

- Maslennikov M.Ya. Obstoyatel'naya koncepciya neobhodima kazhdomu regional'nomu zakonu ob administrativnoy otvetstvennosti // Administrativnoe pravo i process. 2007. № 6 .

- $\quad$ Rogacheva O.S. K voprosu o neobhodimosti modernizacii zakonodatel'stva Rossiyskoy Federacii ob administrativnyh pravonarusheniyah // Administrativnoe pravo i process. 2011. № 11. 
Закон и правопорядок

- Rogacheva O.S. Effektivnost' norm administrativno-deliktnogo prava: monografiya. Voronezh: Izdatel'stvo Voronezhskogo gosudarstvennogo universiteta. 2011.
- $\quad$ Salischeva N.G. O nekotoryh tendenciyah razvitiya zakonodatel'stva ob administrativnoy otvetstvennosti v Rossii v sovremennyy period // Administrativnoe pravo i process. 2009. № 5 . 